\title{
Chemical composition of five loquat cultivars planted in Brazil
}

\author{
Composição química de cinco cultivares de nêsperas plantadas no Brasil
}

\author{
Patrícia Nagai HASEGAWA, Adelia Ferreira de FARIA², Adriana Zerlotti MERCADANTE², Edvan Alves CHAGAS ${ }^{3}$, \\ Rafael PIO ${ }^{4}$, Franco Maria LAJOLO ${ }^{1}$, Beatriz Rosana CORDENUNSI ${ }^{1}$, Eduardo PURGATTO ${ }^{1 \star}$
}

\begin{abstract}
Loquat is a fruit with high market value cultivated in Southeast Brazil. Despite of this, there are little details about its quality characteristics. Fruits from five loquat cultivars, developed using genetic breeding, were analyzed to assess their compositional traits. The cultivars Centenária, Mizuho, Mizumo, Néctar de Cristal and Mizauto were selected based on their high productivity and resistance to diseases. Soluble sugars, organic acids, and carotenoids were quantified using liquid chromatography. The cultivar (cv.) with the highest total sugar concentration was Mizumo and the lowest concentration was found in Centenária. The main sugar detected was sucrose, and the malic acid was the major organic acid. Ascorbic acid was detected in small amounts. The total dietary fiber contents were almost the same in all cultivars. The major carotenoids detected were $\beta$-carotene and $\beta$-cryptoxanthin, except for the cultivar Nectar de Cristal, a white pulp loquat. These results contribute to the knowledge about de physiology of loquat fruit, an interesting raw material due to its nutritional and sensorial characteristics. Furthermore, the results obtained could help to identify the most appropriate use of the loquats with different attributes either for consumption in natura or for industrial processing.
\end{abstract}

Keywords: ripening; Eriobotrya japonica; genetic breeding; $\beta$-carotene.

\section{Resumo}

A nêspera é uma fruta de alto valor de mercado cultivada no sudeste do Brasil. Apesar disso, há poucos detalhes sobre suas características de qualidade. Frutas de cinco cultivares de nêsperas, desenvolvidas por melhoramento genético, foram analisadas para avaliar sua composição química. As cultivares Centenária, Mizuho, Mizumo, Néctar de Cristal e Mizauto foram selecionadas com base em sua alta produtividade e resistência a doenças. Os açúcares solúveis, ácidos orgânicos e carotenoides foram quantificados por cromatografia líquida de alta eficiência. A cultivar com a maior concentração de açúcares totais foi a Mizumo e a com menor a cv. Centenária. O principal açúcar detectado foi a sacarose e o ácido málico, o principal ácido orgânico. O ácido ascórbico foi detectado apenas em pequenas quantidades. O conteúdo de fibra alimentar total foi praticamente o mesmo em todas as cultivares. Os carotenoides principais foram $\beta$-caroteno e $\beta$-criptoxantina, exceto na cv. Néctar de Cristal, uma nêspera de polpa branca. Estes resultados contribuem para o conhecimento da fisiologia das diferentes cultivares de nêspera e podem ajudar a direcionar seu uso mais apropriado, seja para o consumo in natura ou para o processamento industrial, visto ser uma matéria-prima interessante, devido às suas características nutricionais e sensoriais.

Palavras-chave: amadurecimento; Eriobotrya japonica; melhoramento genético; $\beta$-caroteno.

\section{Introduction}

The loquat tree (Eriobotrya japonica Lindl.), a fruit in the Rosaceae family, originated in China and has been widely cultivated for commercial purposes since the $19^{\text {th }}$ century. Currently, the main loquat producers are China and Spain producing 200,000 and 42,000 tons, respectively, each year. In Brazil, loquat production is concentrated in the state of São Paulo, mainly in the city of Mogi das Cruzes. In spite of being lower than in the primary production countries, the Brazilian production of this crop has a significant potential for expansion due to favorable climatic conditions.

This species adapts very well in temperate and subtropical areas requiring an average temperature of about $20^{\circ} \mathrm{C}$. The loquat is agriculturally labor-intensive and sensitive to strong winds, but it responds well to irrigation and adapts well to different soils, as long as the soil is well-drained (HAIRDO; JUNQUEIRA, 1997). The propagation of the loquat tree can be done using seeds or seedlings grafted onto another loquat tree or a quince tree (OJIMA et al., 1999).

The loquat is classified as a non-climacteric fruit since no respiratory peaks of ethylene are registered either from the attached fruit or after harvest. However, Amorós et al. (2003) detected a significant production of ethylene during the ripening for five Spanish loquat cultivars. This observation may have contributed to the re-classification of the loquat as a climacteric

\footnotetext{
Recebido para publicação em 13/11/2008

Aceito para publicação em 16/5/2009 (003943)

${ }^{1}$ Laboratório de Química, Bioquímica e Biologia Molecular de Alimentos, Departamento de Alimentos e Nutrição Experimental, Faculdade de Ciências Farmacêuticas,

Universidade de São Paulo - USP, Avenida Lineu Prestes 580, Bloco 14, CEP 05508-900, São Paulo - SP, Brazil, E-mail: epurgatt@usp.br.

2 Departamento de Ciências dos Alimentos, Faculdade de Engenharia de Alimentos, Universidade Estadual de Campinas - UNICAMP, CP 6121, CEP 13083-862,

Campinas - SP, Brazil

3 Instituto Agronômico, Centro APTA Frutas, Avenida Luiz Pereira dos Santos, 1500, Bairro Currupira, CEP 13214-820, Jundiaí- SP, Brazil

${ }^{4}$ Universidade Estadual do Oeste do Paraná - UNIOESTE, Rua Pernambuco, 1777, CP 1008, CEP 85960-000, Marechal Cândido Rondon - PR, Brazil

${ }^{*}$ A quem a correspondência deve ser enviada
} 
fruit by some authors. In other words, the classification of loquat is controversial.

During ripening, many metabolic changes in the fruit lead to the development of color, texture, and flavor making the fruit acceptable to consumers and subsequently establishing the nutritional and sensorial quality, as well as the shelf-life of the fruit.

Unripe loquat fruit is green and changes to orange or yellow once it ripens. The predominant organic acid in the green fruit is malic acid, which accounts for $90 \%$ of all acids. There are small amounts of citric, succinic, furmaric, tartaric, and ascorbic acid as well (DING et al., 1998). During ripening, the concentration of these organic acids decreases because they are used as a source of energy for respiratory metabolism, and they also may be used as a source of carbon for the production of sugars, which contributes to the sweetness of the fruit. In the loquat, the main sugars that accumulate during ripening are glucose, fructose, sucrose, and sorbitol (AMORÓS et al., 2003). Galactose has also been found in small quantities (next to $0.1 \%$ ) (DING et al., 1998). The pulp of the loquat also contains carotenoids (mainly $\beta$-carotene and $\beta$-cryptoxanthin), vitamins B1 and B2, and nicotinamide (SOUCI; FACHMANN; KRAUT 1994; DING et al., 1998).

The textural changes of the fruit are characterized by the softening of the pulp due to alterations in the molecular structure of the cell wall and middle lamella (BRUMMELL, 2006). The loss of firmness of the fruit is a problem in harvested loquats because this increases their susceptibility to injuries and deterioration of quality.

Loquat cultivars are classified commercially according to pulp color as either orange or white. In Brazil, more precisely in São Paulo State, the most commonly commercially cultivars are the Mizuho, Precoce de Itaquera, and Fukuhara loquat cultivars (OJIMA et al., 1999). Other cultivars may also be found, such as Mogi, Centenária (IAC 1567-420), Mizumo (IAC 1567-411), Mizauto (IAC 167-4), and Néctar de Cristal (IAC 866-7). The last four cultivars were developed by the Instituto Agronômico de Campinas - IAC (Agronomical Institute of Campinas), São Paulo State, Brazil as part of a genetic breeding program using classical hybridization protocols.

These new loquat varieties cultivated in Brazil were selected and developed because of their production potential, preferential resistance to disease, low susceptibility to mechanical damage, and low incidence of purple stain, a blemish, similar to sunburn, which affects the epidermis and harms the general appearance of the fruit. However, additional information about these cultivars is lacking.

In this context, the aim of this work was to evaluate the physicochemical characteristics of the Mizuho, Centenária, Mizumo, Mizauto, and Néctar de Cristal loquat cultivars, as well as their physiological behavior (i.e., ethylene production and respiration during ripening). This characterization is important and necessary to provide an understanding of the potential that these fruits offer in terms of consumption in natura or for industrial processing.

\section{Materials and methods}

\subsection{Materials}

Five loquat cultivars were analyzed: Centenária, Mizumo, Néctar de Cristal, Mizauto, and Mizuho. Except for Mizuho, the cultivars were obtained through classic genetic breeding (hybridization) and selected by the Instituto Agronômico de Campinas - IAC, mainly for their sensorial quality and yield. The fruits were produced at the Centro APTA-Frutas, located in the city of Jundiaí, São Paulo State (23 $8^{\prime} \mathrm{S}$ and $46^{\circ} 55^{\prime} \mathrm{W}$; altitude $700 \mathrm{~m}$ ), and were harvested at the commercial ripening stage from August to September, 2005. The fruits (approximately seventy for each cultivar, 14 to 18 weeks after anthesis, depending on the cultivar) were harvested from the middle of each plant, and were selected according to size $(4-6 \mathrm{~cm}$ from the peduncle to the inflorescence) and skin color (orange except for Néctar de Cristal that was light yellow). For each cultivar, 50 fruits were selected and taken to the laboratory immediately. There, they were rinsed with deionized water and dried using paper towels. Thirty fruits were used for respiration and ethylene production analyses and were stored at room temperature $\left(25^{\circ} \mathrm{C}\right)$ under controlled relative humidity (85\%). Respiration ( $\mathrm{CO}_{2}$ levels) and ethylene production were measured daily for each cultivar from the day of harvest to the beginning of senescence. For the physicochemical analyses such as moisture, dietary fiber, sugar, and organic acid content, twenty fruits of each cultivar were selected on the day of harvest, peeled, frozen in liquid nitrogen, and maintained at $-80{ }^{\circ} \mathrm{C}$.

\section{Characteristics of each cultivar}

Mizuho. This cultivar was obtained by crossing Tanaka with Kusunoki and was introduced into Brazil by Japanese immigrants in 1950 . The fruits are big $(70.0 \pm 10.0 \mathrm{~g}$ on average), yellow-orange and delicate and have a slight sweet-acid flavor. This cultivar has susceptibility to purple stain (similar to sunburn), which affects the epidermis and mars the appearance of the fruit.

Centenária (IAC 1567-420). This cultivar was produced by crossing Mizuho with Mogí, and was developed by the IAC. The fruits are big (60.0 $\pm 5.0 \mathrm{~g}$ on average) and the skin is light orange. It is less susceptible to purple stain and it is attractive with a uniform shape and color. The pulp is very thick, light orange, tender, and juicy.

Mizumo (IAC 1567-411). This cultivar is a cross between Mizuho and Mogí, and was also developed by the IAC. The fruits are big (65.0 $\pm 10.0 \mathrm{~g}$, on average) and round, the skin is orange, and sometimes it is lightly suberified and susceptible to purple stain. The pulp of the fruit is thick, light orange, and has a good consistency being soft and juicy. The flavor of the fruit is pleasant, and it has a sweet-acid taste that is well-balanced.

Mizauto (IAC 167-4). This cultivar originated through selffertilization of the cultivar Mizuho, which was accomplished by the IAC. The oval fruits are big (60 $\pm 10.0 \mathrm{~g}$, on average), their skin is dark orange, and they are less susceptible to purple stain. 
The pulp is very thick, firm, and juicy, and it has a sweet-acid taste.

Néctar de Cristal (IAC 866-7). This cultivar was developed by the IAC and originated from the free pollination of the Togoshi cultivar, which was also introduced into Brazil by Japanese immigrants in 1966. The fruits are medium in size (30 - $40 \mathrm{~g}$ on average), very round, and the skin is light yellow and practically free of purple stain. The pulp is of medium thickness, brilliant white, soft, and very juicy with a very sweet flavor. It is the only cultivar in Brazil that has fruits with white pulp.

\section{Respiration and ethylene production}

The measurements were carried out using a gas chromatograph (Hewllett-Packard, model 6890, Palo Alto, USA) coupled to a Flame Ionization Detector (FID) for ethylene or to a Thermal Conductivity Detector (TCD) for $\mathrm{CO}_{2}$. The column was identical for both gases: HP Plot Q (30 m, I.D. $0.53 \mathrm{~mm}$, $40 \mu \mathrm{m}$, Hewlett-Packard, Palo Alto, USA). The injector and the detector temperatures were 200 and $250^{\circ} \mathrm{C}$, respectively, and the isothermal temperature was $30^{\circ} \mathrm{C}$. The flux of helium for $\mathrm{CO}_{2}$ and ethylene were 4 and $1 \mathrm{~mL} \cdot \mathrm{min}^{-1}$, respectively. The samples were injected in Split mode for $\mathrm{CO}_{2}(50: 1)$ and in Pulsed Split mode for ethylene ( 20 psi for 2 minutes). For the analyses, ten fruits were enclosed in a $1 \mathrm{~L}$ jar (3 jars for each cultivar) and after 1 hour, aliquots of the headspace air were injected into the gas chromatograph using a gas-tight syringe. The volumes injected were 1 and $10 \mathrm{~mL}$ for $\mathrm{CO}_{2}$ and ethylene, respectively. The calculations were done in comparison to certified standards of the two gases (Air Liquid, São Paulo, Brazil)

\section{Dietary fiber and moisture}

The dietary fiber was measured using the enzymaticgravimetric method according to Prosky et al. (1988), and the moisture was determined based on weight loss after drying the fruit in an oven $\left(105^{\circ} \mathrm{C}\right)$ until reach constant weight. At least three replicates of each sample were analyzed for fiber and moisture content.

\section{Soluble sugars}

Sugars were extracted from the fruit pulp, at a ratio of $1: 4(\mathrm{~m} / \mathrm{v})$, three successive times with $80 \%$ ethanol $(\mathrm{v} / \mathrm{v})$ at $80{ }^{\circ} \mathrm{C}$. After centrifugation $(10,000 \times \mathrm{g}$, for 10 minutes at $25^{\circ} \mathrm{C}$ ), the supernatant was transferred to a $25 \mathrm{~mL}$ volumetric flask and the volume was topped up with $80 \%$ ethanol. An aliquot of $1 \mathrm{~mL}$ of each ethanolic extract was evaporated under vacuum in a "Speedvac" system (Savant, Co, Milford, USA). The volume was reconstituted with deionized water. The contents of soluble sugars were analyzed by HPLC-PAD (Pulsed-Amperometric Detector) (Dionex, model DX500, Sunnyvale, USA). This equipment was coupled to a pulsed amperometric detector using a CarboPac PA $1(4.0 \times 250 \mathrm{~mm})$ column (Dionex), $18 \mathrm{mM} \mathrm{NaOH}$ as mobile phase and isocratic flow of $1 \mathrm{~mL} / \mathrm{min}^{-1}$. The extractions were performed in triplicate for each sample.

\section{Organic acids}

The extraction of organic acids was carried out in triplicate with deionized water (ratio 1:2 m/v). The sample was processed in a Potter-type homogenizer for 1 minute (in an ice bath) and centrifuged at $10,000 \times \mathrm{g}$ for 10 minute at $4{ }^{\circ} \mathrm{C}$. The organic acids in the supernatant were analyzed by HPLC-DAD (Diode Array Detector) according to the method used by Amorós et al. (2003).

For the ascorbic acid analysis, the extractions were carried out in triplicate for each sample. One gram of loquat pulp from each sample was homogenized with one $\mathrm{mL}$ of $6 \%$ metaphosphoric acid solution using a Potter homogenizer and then centrifuged at $10,000 \times \mathrm{g}$ for 20 minute at $4{ }^{\circ} \mathrm{C}$. An aliquot of $250 \mu \mathrm{L}$ of the supernatant was mixed with $250 \mu \mathrm{L}$ of $0.1 \mathrm{M}$ dithiothreitol in $0.5 \mathrm{M}$ Tris- $\mathrm{HCl}$ buffer ( $\mathrm{pH}$ 6.0) and incubated for 30 minute at room temperature. After incubation, $500 \mu \mathrm{L}$ of the mobile phase $(2 \mathrm{mM} \mathrm{KCl}, \mathrm{pH} 2.5)$ was added to the extract. Aliquots of $10 \mu \mathrm{L}$ were injected into a chromatograph (Hewllett-Packard, model 1100, Palo Alto, USA) equipped with a NucleoSil C ${ }_{18}(3.6 \times 150 \mathrm{~mm}, 5 \mu \mathrm{m}$ particle size, Agilent, Palo Alto, USA), a diode array detector (settled up to $245 \mathrm{~nm}$ ). The run was done isocratically at a flow rate of $0.8 \mathrm{~mL} \cdot \mathrm{min}^{-1}$. The column compartment temperature was adjusted to $35^{\circ} \mathrm{C}$. The ascorbic acid content was determined by external calibration (Sigma Co, St Louis, USA).

\section{Carotenoid analysis}

The carotenoids were exhaustively extracted (three extractions per sample) from the pulp (10 to $15 \mathrm{~g}$ ) using acetone, transferred to petroleum ether $\left(30-70{ }^{\circ} \mathrm{C}\right) /$ diethyl ether (2:1), and saponified overnight at room temperature with $10 \%$ methanolic $\mathrm{KOH}$. The alkali was fully removed by washing with water, and then the solvent was entirely evaporated in a rotary evaporator $\left(\mathrm{T}<40^{\circ} \mathrm{C}\right)$ (DE ROSSO; MERCADANTE, 2007).

The analysis was carried out in a Waters (Wilmington, USA) HPLC equipped with quaternary pumps (model 600), online degasser, a Rheodyne injection valve with a $20 \mu \mathrm{L}$ loop, an external oven with temperature control, and a photo-diode array detector (PDA) (Waters, model 996). The data acquisition and processing were done using Millennium Waters software. The UV-visible spectra were obtained between 250 and $650 \mathrm{~nm}$ and the chromatograms were processed at $450 \mathrm{~nm}$.

The carotenoid separation was carried out on a $\mathrm{C}_{30} \mathrm{YMC}$ column $(5 \mu \mathrm{m}, 250 \times 4.6 \mathrm{~mm}$ i.d.) (Waters) using a linear gradient of $\mathrm{MeOH}$ with $0.1 \%$ triethylamine (TEA)/MTBE as the mobile phase from $95: 5$ to $70: 30$ for 30 minutes followed by 50:50 for 20 minutes. The flow rate was $1.0 \mathrm{~mL} \cdot \mathrm{min}^{-1}$, and the column temperature was $29^{\circ} \mathrm{C}$.

The major carotenoids were identified according to the retention time and the UV/visible spectrum $(\lambda$ and spectral fine structure - \%III/II) by comparing them to standards analyzed under the same conditions reported in the literature (BRITTON; LIAAEN-JENSEN; PFANDER, 2004; DE ROSSO; MERCADANTE, 2007). 
The major carotenoids were quantified using HPLC with external calibration curves for $\beta$-cryptoxanthin and $\beta$-carotene.

\section{Soluble solids}

One gram of the frozen pulp of the fruit from each cultivar was ground in a mortar and the powder was transferred to a microcentrifuge tube and left to thaw at room temperature. The pulp was centrifuged at $10,000 \times \mathrm{g}$ for 15 minutes, and the soluble solids (SS) content of the supernatant was determined with a manual refratometer (ATAGO model 9208, 0 - 90\%, Saitama, Japan). The SS were expressed in ${ }^{\circ}$ Brix. The extractions were done in triplicate for each sample.

\section{Statistical analysis}

The means were compared to determine the influence of each cultivar on the dependent variable. Data analyses were performed using the Tukey's test $(p<0.05)$ in the Statistical Analysis System (SAS for Windows v.9.0, SAS Institute, Inc., Cary, NC, USA) software package.

\section{Results and discussion}

\subsection{Respiration and ethylene production}

Different respiration profiles during ripening were produced by the fruits of the five loquat cultivars that also differed in relation to the peak of $\mathrm{CO}_{2}$ released (Figure 1). The lowest levels of $\mathrm{CO}_{2}$ were released by the Centenária cultivar (about $30 \mathrm{mg} \cdot \mathrm{Kg} \mathrm{FW}^{-1} \cdot \mathrm{h}^{-1}$ ) throughout ripening with virtually no change. A similar profile was observed for the Mizuho loquat, but the level of respiration was slightly higher than that observed for Centenária. The highest levels of respiration were recorded for the Mizauto and Mizumo cultivars, in which respiratory peaks were detected on the $2^{\text {nd }}$ day after harvest (DAH) (238 and $240 \mathrm{mg} \mathrm{CO}_{2} \cdot \mathrm{kg} \mathrm{FW}^{-1} \cdot \mathrm{h}^{-1}$, respectively) decreasing thereafter. In contrast, for the Néctar de Cristal, the respiration rate was low $\left(11 \mathrm{mg} \mathrm{CO}_{2} \cdot \mathrm{Kg} \mathrm{FW}^{-1} \cdot \mathrm{h}^{-1}\right)$ on the $1^{\text {st }} \mathrm{DAH}$, but the respiratory rate increased and peaked on the $4^{\text {th }} \mathrm{DAH}$ (146 mg CO $2 . \mathrm{Kg} \mathrm{FW}^{-1} \cdot \mathrm{h}^{-1}$ ).

Respiration is a determining factor in the post-harvest life of the fruit and it is well known that there is an inverse relationship between respiratory rate and shelf-life. This is in accordance with the observation that loquats from Néctar de Cristal, Mizauto, and Mizumo cultivars may have a shorter post-harvest life in comparison to Centenária and Mizuho because they had lower respiration rates following harvest (unpublished data).

In all cultivars analyzed, some elevation of ethylene production during the post-harvest period was observed (Figure 1). Low levels of ethylene were detected one day after harvest in the Centenária, Néctar de Cristal, and Mizuho cultivars, while Mizauto and Mizumo loquat cultivars had higher initial production rates (about 8 and $11 \mu \mathrm{L}$ of ethylene. $\mathrm{Kg}^{-1} \cdot \mathrm{h}^{-1}$, respectively). The highest levels of ethylene were detected two DAH in the Néctar de Cristal, Mizumo and Mizauto loquats with rates of about 3,9 , and $12 \mu \mathrm{L}$ of ethylene. $\mathrm{Kg}^{-1} \cdot \mathrm{h}^{-1}$,

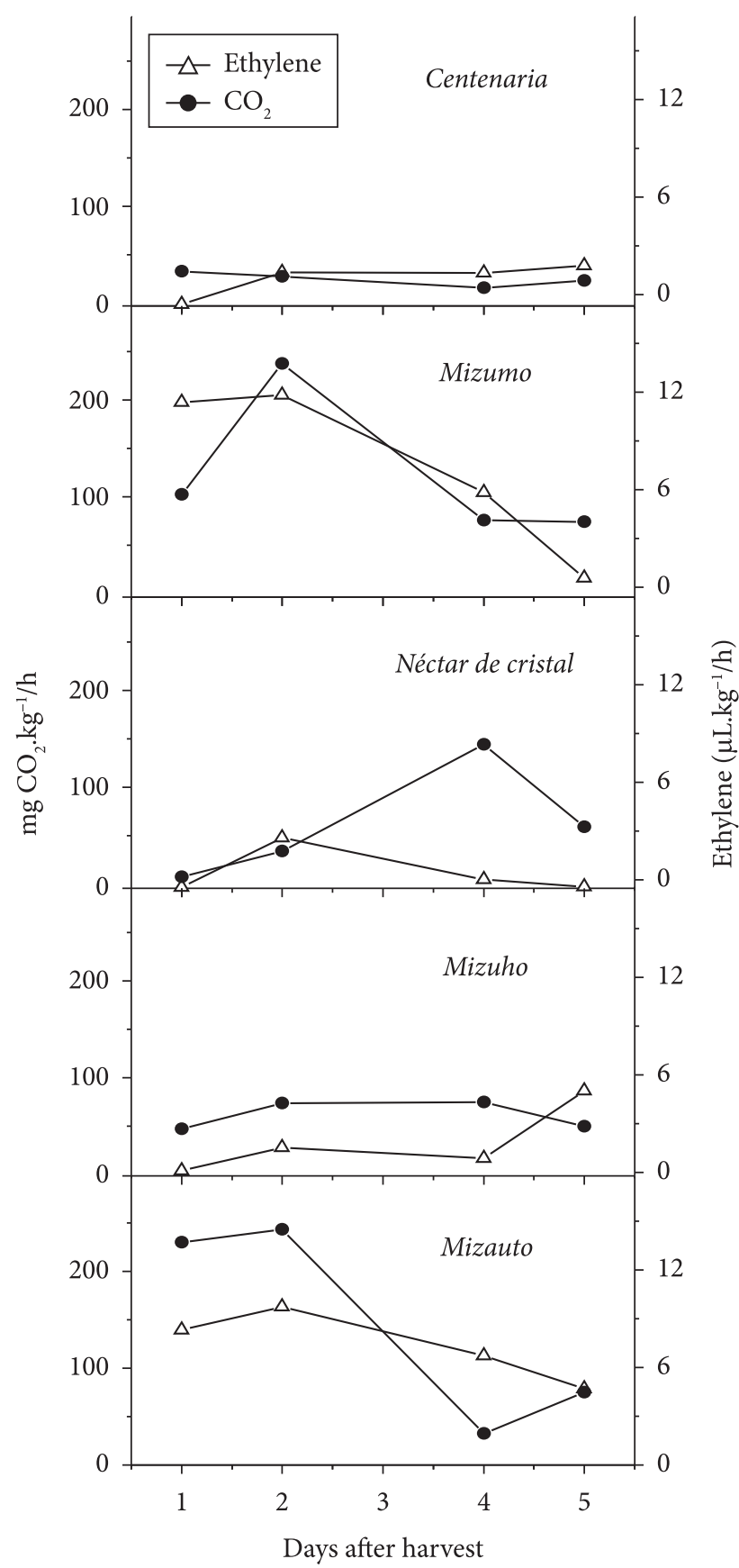

Figure 1. Respiration (-๑-) and ethylene production (- $\Delta$-) profiles after fruit harvest for five loquat cultivars. The data are means \pm standard deviation of three replicates.

respectively. However, for the cultivars Centenária and Mizuho, the highest ethylene production was observed on the fifth $\mathrm{DAH}$ (2.4 and $5 \mu \mathrm{L}$ of ethylene. $\mathrm{Kg}^{-1} \cdot \mathrm{h}^{-1}$, respectively). Among all cultivars analyzed, Mizumo and Mizauto produced the highest amounts of ethylene post-harvest, and are higher than the maximum values found in the literature. For instance, other researchers have detected ethylene in fruits of the cultivar Mogi (1.4 $\mu \mathrm{L} \cdot \mathrm{Kg}^{-1} \cdot \mathrm{h}^{-1}$, DING et al., 2002) Magdall $\left(3.4 \mu \mathrm{L} \cdot \mathrm{Kg}^{-1} \cdot \mathrm{h}^{-1}\right.$, AMORÓS et al., 2003). 
The comparison between the respiration profiles and the ethylene production for the five loquat cultivars revealed that the intensity of the two physiological processes occurred in a similar way, i.e., those that had high ethylene production (Mizumo, Mizauto, and Néctar de Cristal) also had high respiration rates although they were not simultaneous in all cases. Therefore, in spite of the loquat being considered a non-climacteric fruit, the increase in ethylene production may have stimulated the respiratory activity of these cultivars and accelerated the metabolic process of ripening, which is a typically climacteric behavior.

In previous research, typical non-climacteric behavior was described for other loquat cultivars with a gradual decrease in ethylene production and respiration during the postharvest period [cultivar Mogí (DING et al., 1998) and Algerie (AMORÓs et al., 2003)]. In low temperature (1 to $10{ }^{\circ} \mathrm{C}$ ), storage tests with the Mogí, loquat, the respiratory intensities, and ethylene production decreased. As a consequence, their chemical characteristics were preserved and their shelf-life was extended (DING et al., 1998). Similar results were obtained for Precoce de Itaquera, when stored in $6{ }^{\circ} \mathrm{C}$ compared to $18{ }^{\circ} \mathrm{C}$ (CAMPOS et al., 2007).

\subsection{Chemical composition}

The moisture level varied from 86 to $91 \%$ of fresh weight (FW) for the five cultivars analyzed (Table 1). The high water content of the fruits may explain the texture characteristics of the loquat pulp as being firm, fleshy, and succulent (OJIMA et al., 2002). The Mizumo and Mizuho fruits had the highest moisture content with 90 and 91\% (FW), respectively.

The moisture content is one of the most important parameters for the fruit processing, mainly for the preparation of jellies and jams. The moisture content of the loquat fruits analyzed were not very high and were similar to those found in pineapple and peach (SOUCI; FACHMANN; KRAUT, 1994), fruits commonly used in compotes and consumed in dehydrated form too. Thus, the loquat fruits could be used for the preparation of dehydrated products constituting an interesting alternative for the industry.

The soluble solids (Table 1) of the five loquat cultivars varied from $8.25^{\circ}$ Brix (Centenária) to $11.84^{\circ}$ Brix (Mizumo). The difference between the soluble solids and the sum of total soluble sugars (TSSu) and total organic acids (TOA) indicate a significant presence of other compounds that may include vitamins, phenolics, pectins, etc., also dissolved in the fruit juice (SEYMOUR; TAYLOR; TUCKER, 1993).

The balance between sugars and acids is important for the taste of the fruit in general contributing substantially to post-harvest quality. Table 1 shows the results of the sum of the content of the main sugars, i.e. sucrose, glucose, fructose, and sorbitol (total soluble sugars, TSSu) and the organic acids, i.e. malic, citric, and succinic (total organic acids, TOA) to allow the general comparison between the cultivars. The concentrations of ascorbic acid in the five loquat cultivars were analyzed separately due to the nutritional importance of this measurement.

The ascorbic acid (vitamin C) had the lowest concentration among the organic acids in the loquats ranging from $5.28 \mathrm{mg} .100 \mathrm{~g} \mathrm{~g}^{-1} \mathrm{FW}$ in the Centenária to $8.20 \mathrm{mg} 100 \mathrm{~g}^{-1} \mathrm{FW}$ in the Mizumo fruit (Table 1). The vitamin C concentrations for the five cultivars are close to the values reported for other ripe fruits in the Rosaceae family. Apples contain $8.0 \mathrm{mg} .100 \mathrm{~g}^{-1} \mathrm{FW}$ and red plums have $6.8 \mathrm{mg} .100 \mathrm{~g}^{-1} \mathrm{FW}$ (SEYMOUR; TAYLOR; TUCKER, 1993). However, in comparison with fruits rich in vitamin $\mathrm{C}$, such as oranges and Barbados cherry that contain about $40 \mathrm{mg} .100 \mathrm{~g}^{-1} \mathrm{FW}$ and $1.05 \mathrm{~g} .100 \mathrm{~g}^{-1} \mathrm{FW}$ respectively, loquats are a poor source of this vitamin.

The balance between sweetness and acidity, expressed as the ratio of the total soluble sugars (TSSu) and the total organic acid content of (TOA) indicated that Mizumo had the highest value (15.0), the cultivars Mizuho and Néctar de Cristal had intermediate values (7.4 and 7.6, respectively), and the lowest values were found in the Centenária and Mizauto cultivars (5.0 and 5.4, respectively). The highest values for the ratio of sugar/ acid found in some loquat cultivars indicate that the sugar content is high making the fruit sweet and more suited to in natura consumption.

The examination of the cultivars that had the lowest values of the TSSu/TOA ratio revealed that low levels of sugars may allow for an enhanced perception of the acid flavor. Thus, those cultivars with lower total soluble sugar content may have less acceptability for in natura consumption, but may be suited for industrial processing (production of compotes and jellies). For example, producers separate apples for processing and consumption by using a limit of 20 for the ratio of total reducing sugars/titratable total acidity. Fruits with low sugar values are heavily exploited for industrial purposes because they have high

Table 1. Chemical composition of the fruits from five loquat cultivars harvested at the commercial mature stage.

\begin{tabular}{|c|c|c|c|c|c|c|c|}
\hline Cultivar & $\begin{array}{l}\text { Moisture } \\
\left(\mathrm{g} .100 \mathrm{~g}^{-1}\right)\end{array}$ & $\begin{array}{l}\text { TSS }^{1} \\
\left({ }^{\circ} \text { Brix }\right)\end{array}$ & $\begin{array}{c}\mathrm{TSSu}^{2} \\
\left(\mathrm{~g} .100 \mathrm{~g}^{-1}\right)\end{array}$ & $\begin{array}{c}\mathrm{TOA}^{3} \\
\left(\mathrm{~g} .100 \mathrm{~g}^{-1}\right)\end{array}$ & Ratio $^{4}$ & $\begin{array}{c}\mathrm{AA}^{5} \\
\left(\mathrm{mg} .100 \mathrm{~g}^{-1}\right)\end{array}$ & $\begin{array}{c}\text { TDF }^{6} \\
\text { (g.100 g-1) }\end{array}$ \\
\hline Centenária & $88.81 \pm 0.18^{\mathrm{a}}$ & $8.25 \pm 0.61^{c}$ & $4.32 \pm 0.01^{\mathrm{f}}$ & $0.86 \pm 0.11^{\mathrm{k}}$ & 5.02 & $5.28 \pm 0.44^{1}$ & $1.21 \pm 0.09^{n}$ \\
\hline Néctar de cristal & $86.39 \pm 0.14^{\mathrm{b}}$ & $11.0 \pm 0.82^{\mathrm{d}}$ & $7.17 \pm 0.08^{g}$ & $0.94 \pm 0.12^{\mathrm{k}}$ & 7.63 & $5.51 \pm 0.35^{1}$ & $1.32 \pm 0.08^{\mathrm{n}}$ \\
\hline Mizauto & $89.15 \pm 0.06^{\mathrm{a}}$ & $9.50 \pm 0.21^{c}$ & $6.00 \pm 0.02^{\mathrm{h}}$ & $1.11 \pm 0.07^{\mathrm{k}}$ & 5.41 & $5.81 \pm 0.43^{1}$ & $1.19 \pm 0.15^{\mathrm{n}}$ \\
\hline Mizuho & $90.78 \pm 0.03^{\mathrm{a}}$ & $9.50 \pm 0.41^{c}$ & $6.85 \pm 0.09^{g}$ & $0.93 \pm 0.09^{k}$ & 7.36 & $6.81 \pm 0.16^{\mathrm{m}}$ & $1.41 \pm 0.11^{\mathrm{n}}$ \\
\hline Mizumo & $90.43 \pm 0.10^{\mathrm{a}}$ & $11.84 \pm 0.33^{\mathrm{d}}$ & $11.48 \pm 0.12^{\mathrm{i}}$ & $0.76 \pm 0.12^{\mathrm{k}}$ & 15.10 & $8.20 \pm 1.21^{\mathrm{m}}$ & $1.38 \pm 0.09^{\mathrm{n}}$ \\
\hline
\end{tabular}

${ }^{1} \mathrm{TSS}=$ total solid soluble; ${ }^{2} \mathrm{TSSu}=$ total soluble sugars; ${ }^{3} \mathrm{TOA}=$ total organic acid, ${ }^{4}$ Ratio TSS/TSSu; ${ }^{5} \mathrm{AA}=$ ascorbic acid; ${ }^{6} \mathrm{TDF}=$ total dietary fiber; all values are mean $\pm \mathrm{SD}$ ( $\mathrm{n}=3$ ).

The values in the same column marked with different letters are significantly different $(p<0.05)$. 
acidity (CZELUSNIAK et al., 2003; PAGANINI et al., 2004) and would have low acceptability for in natura consumption. Corrections of the sugar or acidity content, made in processed products (jams, for instance) can circumvent possible problems with a low sugar content in the fruit pulp. The classification system for fruit cultivars constitutes an easy way to maximize commercial use, and this method could be established for the loquat using studies on sensorial quality and processing.

Sucrose was the predominant sugar for all cultivars

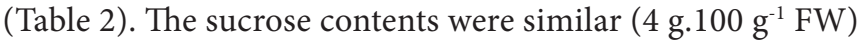
in Néctar de Cristal, Mizauto, and Mizuho fruits, the lowest content was found in the Centenária cultivar $\left(2.0\right.$ g.100 g $\left.\mathrm{g}^{-1} \mathrm{FW}\right)$ and the highest in Mizumo (4.96 g.100 g $\mathrm{g}^{-1} \mathrm{FW}$ ). The major sugar differences among the loquats were found for glucose, fructose, and sorbitol; these variations are important for the formation of different flavors (SEYMOUR; TAYLOR; TUCKER, 1993). Fructose, glucose, and sucrose are the most common soluble sugars found in ripe fruits, and they have different sweetness levels; fructose is the sweetest. Therefore, in spite of the high concentration of sucrose, fructose content may play a major role in determining the main differences between flavors from the different loquat varieties.

Fructose content was slightly higher than glucose for all cultivars, except for Néctar de Cristal, in which the fructose was more than twice as high as glucose. A possible explanation is that glucose is used in the respiratory pathway. Also, it may be that, apart from sucrose, other sources such as sorbitol may contribute to the increase of fructose in the fruit. This may be the case for the Néctar de Cristal loquat, which showed the highest sorbitol content ( $\left.1.1 \mathrm{~g} .100 \mathrm{~g}^{-1} \mathrm{FW}\right)$.

The acidity of the fruit is attributed mainly to the organic acid content, which may vary between cultivars and depend on the maturation stage of the fruit. The main organic acid detected in ripe loquats was malic acid, and in smaller concentrations, citric and succinic acids (Table 3 ). The amount of malic acid among cultivars ranged from 750 to $980 \mathrm{mg} .100 \mathrm{~g}^{-1}$ (FW). It was, therefore, mainly responsible for the acidity of the fruit. There was a great variation in the citric acid content among the cultivars with the lowest content found in the Néctar de Cristal (32 mg.100 g $\mathrm{g}^{-1} \mathrm{FW}$ ) and the highest in Mizumo (150 mg.100 g-1 FW). The succinic acid content ranged from 14 to $25 \mathrm{mg} .100 \mathrm{~g}^{-1} \mathrm{FW}$ among the cultivars. These results are in accordance to the Amóros et al. (2003) studies of five Spanish loquat cultivars, in which they observed similar values for the same organic acids.

The total dietary fiber of the loquat fruits varied from

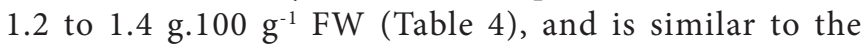
pineapple (1.34 g.100 g-1 FW, BARTOLOME; RUPEREZ, 1995). The insoluble fiber fractions were slightly higher than the soluble ones, with proximal values among the cultivars, and $0.73 \mathrm{~g} .100 \mathrm{~g}^{-1} \mathrm{FW}$ being the medium value. However, the soluble fraction had wider variation among cultivars, from

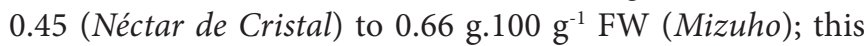
influenced the amount of total fiber content in all fruits. The cultivars that showed the highest values of total dietary fiber were Mizumo and Mizuho (1.4 g.100 g-1 FW), and the lowest values were found in the Mizauto and Centenária loquats (1.2 g.100 g $\left.\mathrm{g}^{-1} \mathrm{FW}\right)$.

Figure 2 shows the chromatograms obtained from Néctar de Cristal and Mizauto cultivars. The carotenoid profiles of Centenária, Mizuho, and Mizumo cultivars were similar to the Mizauto. According to Figure 2, the major carotenoids were all-trans- $\beta$-carotene and all-trans- $\beta$-cryptoxanthin for all cultivars. This was previously reported for all different loquat cultivars evaluated by other researchers (GROSS et al., 1973; KON; SHIMBA, 1988; GODOY; RODRIGUEZ-AMAYA, 1995).

Table 2. Soluble sugars of ripe fruit from five loquat cultivars.

\begin{tabular}{|c|c|c|c|c|c|}
\hline Cultivar & $\begin{array}{c}\text { Sorbitol } \\
\left(\mathrm{g} .100 \mathrm{~g} \mathrm{FW}^{-1}\right)\end{array}$ & $\begin{array}{c}\text { Glucose } \\
\left(\mathrm{g} .100 \mathrm{~g} \mathrm{FW}^{-1}\right)\end{array}$ & $\begin{array}{c}\text { Fructose } \\
\left(\mathrm{g} .100 \mathrm{~g} \mathrm{FW}^{-1}\right)\end{array}$ & $\begin{array}{c}\text { Sucrose } \\
\left(\mathrm{g} .100 \mathrm{~g} \mathrm{FW}^{-1}\right)\end{array}$ & $\begin{array}{c}\text { Total } \\
\left(\text { g. } 100 \mathrm{~g} \mathrm{FW}^{-1}\right)\end{array}$ \\
\hline Centenária & $0.54 \pm 0.06^{\mathrm{a}}$ & $0.93 \pm 0.09^{c}$ & $1.55 \pm 0.13^{\mathrm{f}}$ & $2.70 \pm 0.18^{j}$ & $5.72 \pm 0.46^{\mathrm{m}}$ \\
\hline Néctar de cristal & $1.08 \pm 0.34^{\mathrm{b}}$ & $0.64 \pm 0.04^{\mathrm{d}}$ & $1.54 \pm 0.06^{\mathrm{f}}$ & $3.91 \pm 0.11^{\mathrm{k}}$ & $7.17 \pm 0.55^{\mathrm{m}}$ \\
\hline Mizauto & $0.72 \pm 0.28^{b}$ & $0.50 \pm 0.08^{\mathrm{d}}$ & $0.89 \pm 0.14^{\mathrm{g}}$ & $3.89 \pm 0.32^{\mathrm{k}}$ & $6.00 \pm 0.82^{\mathrm{m}}$ \\
\hline Mizuho & $0.71 \pm 0.16^{\mathrm{b}}$ & $1.00 \pm 0.16^{c}$ & $1.29 \pm 0.06^{\mathrm{h}}$ & $3.85 \pm 0.31^{\mathrm{k}}$ & $6.85 \pm 0.69^{\mathrm{m}}$ \\
\hline Mizumo & $0.80 \pm 0.01^{\mathrm{b}}$ & $1.51 \pm 0.04^{\mathrm{e}}$ & $1.82 \pm 0.09^{\mathrm{i}}$ & $4.96 \pm 0.04^{1}$ & $9.09 \pm 0.18^{n}$ \\
\hline
\end{tabular}

All values are the mean \pm SD $(n=3)$. The values in the same column marked with different letters are significantly different $(\mathrm{p}<0.05)$.

Table 3. Organic acids of ripe fruits from five loquat cultivars.

\begin{tabular}{|c|c|c|c|c|c|}
\hline Cultivar & $\begin{array}{c}\text { Citric } \\
\left(\mathrm{mg} .100 \mathrm{~g} \mathrm{FW}^{-1}\right)\end{array}$ & $\begin{array}{c}\text { Malic } \\
\left(\mathrm{mg} .100 \mathrm{~g} \mathrm{FW}^{-1}\right)\end{array}$ & 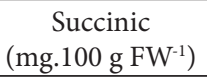 & 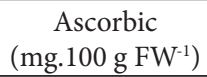 & $\begin{array}{c}\text { Total } \\
\left(\mathrm{mg} .100 \mathrm{~g} \mathrm{FW}^{-1}\right)\end{array}$ \\
\hline Centenária & $82.96 \pm 1.23^{\mathrm{a}}$ & $750.25 \pm 1.63^{\mathrm{e}}$ & $24.71 \pm 1.01^{\mathrm{i}}$ & $0.058 \pm 0.004^{\mathrm{k}}$ & $857.92 \pm 3.87^{\mathrm{m}}$ \\
\hline Néctar de cristal & $31.68 \pm 2.35^{\mathrm{b}}$ & $895.58 \pm 26.31^{\mathrm{f}}$ & $13.78 \pm 0.54^{j}$ & $0.051 \pm 0.003^{\mathrm{k}}$ & $941.05 \pm 29.20^{\mathrm{n}}$ \\
\hline Mizauto & $101.97 \pm 0.55^{\mathrm{c}}$ & $988.05 \pm 24.92^{\mathrm{g}}$ & $23.55 \pm 0.56^{\mathrm{i}}$ & $0.058 \pm 0.004^{\mathrm{k}}$ & $1113.58 \pm 26.03^{\circ}$ \\
\hline Mizumo & $150.14 \pm 17.53^{\mathrm{d}}$ & $587.97 \pm 19.87^{\mathrm{h}}$ & $23.67 \pm 0.75^{\mathrm{i}}$ & $0.082 \pm 0.001^{1}$ & $761.79 \pm 38.15^{\mathrm{p}}$ \\
\hline Mizuho & $84.09 \pm 3.06^{\mathrm{a}}$ & $827.48 \pm 37.57^{\mathrm{f}}$ & $23.02 \pm 0.58^{\mathrm{i}}$ & $0.068 \pm 0.002^{1}$ & $934.60 \pm 41.21^{\mathrm{n}}$ \\
\hline
\end{tabular}

Values are the mean \pm SD $(n=3)$. The values in the same column marked with different letters are significantly different $(\mathrm{p}<0.05)$. 
Table 5 shows the all-trans- $\beta$-carotene and all-trans- $\beta$ cryptoxanthin concentrations obtained from all five loquat cultivars. The fruit from the Néctar de Cristal cultivar showed a different carotenoid profile, with the lowest carotenoid content, and was the only cultivar that showed a $\beta$-carotene $/ \beta$ cryptoxanthin ratio lower than one. These characteristics may be because this cultivar was derived from different cultivars, whereas all other cultivars analyzed in this study, Mizuho, Centenária, Mizumo, and Mizauto had a similar origin. The other four cultivars (Mizauto, Mizuho, Mizumo, and Centenária) had $\beta$-carotene/ $\beta$-cryptoxanthin ratios equal to or higher than 2. Within this group, Centenária had the highest ratio (3.1).

Mizauto had $\beta$-carotene and $\beta$-cryptoxanthin concentrations close to those found in Mizuho. This result makes sense because the cultivar Mizauto was derived from cultivar Mizuho. Mizumo showed $\beta$-carotene and $\beta$-cryptoxanthin concentrations about twice as high as those found in Centenária although both cultivars were obtained from a Mizuho and Mogi cross. Furthermore, these cultivars showed other differences in respiratory activity, ethylene production, and chemical composition (Figure 1, Table 1).

Results reported by other researchers (GROSS et al., 1973 ; KON; SHIMBA, 1988) also showed $\beta$-carotene $\beta$ cryptoxanthin ratio variation among cultivars. According to Kon and Shimba (1988), the cultivar Tanaka had a $\beta$-carotene/ $\beta$-cryptoxanthin ratio of 2.2 , whereas the To $i$ cultivar had a value of 0.7 ; both cultivars are cultivated in Japan. The $\beta$-carotene/ $\beta$-cryptoxanthin ratio was 1.5 in the Golden Nugget cultivar from Israel (GROSS et al., 1973). This ratio was found to be 1.6 in an unspecified cultivar from Brazil (GODOY; RODRIGUEZ-AMAYA, 1995).

The carotenoid composition for all loquat cultivars was determined in the present study. The Tanaka cultivar, whose crossing with cultivar Kusunoki gave rise to the cultivar Mizuho, presented $21.1 \mu \mathrm{g} \beta$-carotene. $\mathrm{g}^{-1} \mathrm{FW}$ and $9.6 \mu \mathrm{g} \beta$-cryptoxanthin $\mathrm{g}^{-1} \mathrm{FW}$ (KON; SHIMBA, 1988). These values are higher than those found in the present study for cultivar Mizuho. On the other hand, the $\beta$-carotene content $\left(7.8 \mu \mathrm{g} . \mathrm{g}^{-1} \mathrm{FW}\right)$ and the $\beta$-cryptoxanthin content $\left(4.8 \mu \mathrm{g} . \mathrm{g}^{-1} \mathrm{FW}\right)$ from the unspecified cultivar from Brazil (GODOY; RODRIGUEZ-AMAYA, 1995) were in the same range as those found for Mizauto and Mizuho cultivars.
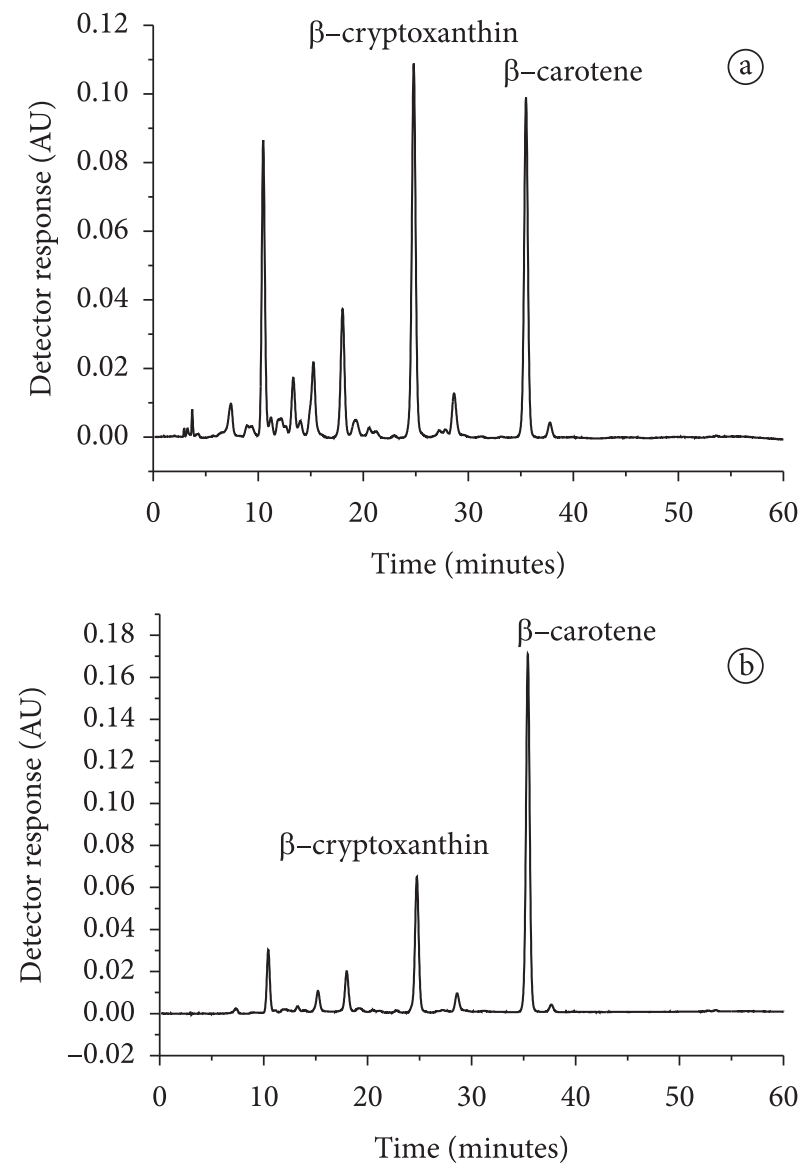

Figure 2. The chromatogram obtained by HPLC-PDA, of the carotenoids from loquat (a) cultivar Néctar de Cristal and (b) cultivar Mizauto. For chromatographic conditions: see text. Processed at $450 \mathrm{~nm}$.

Table 4. Soluble, insoluble and total dietary fiber of ripe fruits from five loquat cultivars.

\begin{tabular}{lccc}
\hline \multirow{2}{*}{ Cultivar } & \multicolumn{2}{c}{ Dietary fiber $\left(\mathrm{g} .100 \mathrm{~g}^{-1} \text { of fresh pulp }\right)^{\star}$} \\
\cline { 2 - 4 } & Soluble & Insoluble & Total \\
\hline Centenária & $0.52 \pm 0.05^{\mathrm{a}}$ & $0.69 \pm 0.04^{\mathrm{c}}$ & 1.21 \\
Néctar de cristal & $0.59 \pm 0.05^{\mathrm{a}}$ & $0.73 \pm 0.02^{\mathrm{c}}$ & 1.32 \\
Mizauto & $0.45 \pm 0.03^{\mathrm{a}}$ & $0.74 \pm 0.04^{\mathrm{c}}$ & 1.19 \\
Mizuho & $0.66 \pm 0.04^{\mathrm{b}}$ & $0.75 \pm 0.03^{\mathrm{c}}$ & 1.41 \\
Mizumo & $0.60 \pm 0.04^{\mathrm{a}}$ & $0.78 \pm 0.02^{\mathrm{c}}$ & 1.38 \\
\hline
\end{tabular}

${ }^{*}$ Values are the mean $\pm S D(n=3)$. The values in the same column marked with different letters are significantly different $(\mathrm{p}<0.05)$.

Table 5. Concentration of major carotenoids from loquat cultivars.

\begin{tabular}{|c|c|c|c|}
\hline Cultivar & all-trans- $\beta$-caroten $e^{\star}\left(\mu \mathrm{g} \cdot \mathrm{g}^{-1}\right)$ & all-trans- $\beta$-cryptoxanthin ${ }^{*}\left(\mu \mathrm{g} \cdot \mathrm{g}^{-1}\right)$ & Ratio $^{* *}$ \\
\hline Centenária & $8.58 \pm 0.86^{\mathrm{a}}$ & $2.78 \pm 0.11^{\mathrm{d}}$ & 3.1 \\
\hline Mizauto & $9.81 \pm 0.64^{\mathrm{a}}$ & $4.80 \pm 0.29^{\mathrm{e}}$ & 2.0 \\
\hline Mizuho & $10.91 \pm 0.23^{\mathrm{a}}$ & $5.58 \pm 0.16^{\mathrm{e}}$ & 2.0 \\
\hline Mizumo & $14.42 \pm 0.01^{\mathrm{b}}$ & $7.15 \pm 0.23^{\mathrm{f}}$ & 2.0 \\
\hline Néctar de cristal & $0.38 \pm 0.02^{\mathrm{c}}$ & $0.55 \pm 0.02^{\mathrm{g}}$ & 0.7 \\
\hline
\end{tabular}

\footnotetext{
* Values are the mean \pm SD $(n=3)$. ${ }^{* *}$ Ratio between all-trans- $\beta$-carotene and all-trans- $\beta$-cryptoxanthin contents. The values in the same column marked with different letters are
} significantly different $(\mathrm{p}<0.05)$. 


\section{Conclusions}

The Néctar de Cristal, Mizumo, and Mizauto cultivars had the highest respiratory rates and higher ethylene production levels. The Centenária and Mizuho cultivars had lower ethylene production and respiratory evolution. The evolution of these processes may occur in parallelly during post-harvest of the loquat fruit, and the ethylene production may stimulate respiratory activity during the ripening process and senescence. For these or other cultivars of loquats to be used in the in natura market, it is necessary to store them in such a way as to reduce respiratory activity (e.g., low temperature) to decrease the perishability of these fruits.

Although the results suggest that the fruits of all five cultivars evaluated can be indicated for in natura consumption, particularly Mizuho, Mizumo, and Néctar de Cristal presented the best characteristics for this purpose, i.e., the highest contents of water, soluble sugars, ascorbic acid, and total dietary fiber. On the other hand, the highest content of soluble fiber can be determinant to direct fruits of the cultivars Mizauto and Centenária to industrial processing once this characteristic is desirable for the production of jams, jellies, and similar products.

\section{Acknowledgements}

The authors are grateful for the financial support provided by the foundations FAPESP (The State of São Paulo Research Foundation), CNPq (The National Council for Scientific and Technological Development), and CAPES (Brazilian Research Supporting Foundation).

\section{References}

AMORÓS, A. et al. Physico-chemical and physiological changes during fruit development and ripening of five loquat (Eriobotrya japonica Lindl.) cultivars. Food Science and Technology International, v. 9, n. 1, p. 43-51, 2003.

BARTOLOME, A. P.; RUPEREZ, P. Dietary fiber in pineapple fruit. European Journal of Clinical Nutrition, v. 49, suppl. 3, p. S261-S263, 1995.
BRITTON, G.; LIAAEN-JENSEN, S.; PFANDER, H. (Eds.). Carotenoids - Handbook. Basel: Birkhauser, 2004. (Compiled by A. Z. Mercadante e E. S. Egeland).

BRUMMELL, D. A. Cell wall disassembly in ripening fruit. Functional Plant Biology, v. 33, n. 2, p. 103-119, 2006.

CZELUSNIAK, C. et al. Qualidade de maçãs comerciais produzidas no Brasil: aspectos físico-químicos. Brazilian Journal of Food Technology, v. 6, n. 1, p. 25-31, 2003.

DE ROSSO, V. V.; MERCADANTE, A. Z. Identification and quantification of carotenoids, by HPLC-PDA-MS/MS from Amazonian fruits. Journal of Agricultural and Food Chemistry, v. 55, n. 13, p. 5062-5072, 2007.

DING, C. K. et al. Effects of storage temperatures on physiology and quality of loquat fruit. Postharvest Biology and Technology, v. 14, n. 3, p. 309-315, 1998.

DING, C. K. et al. Modified atmosphere packaging maintains postharvest quality of loquat fruit. Postharvest Biology and Technology, v. 24, n. 3, p. 341-348, 2002.

GODOY, H.; AMAYA, D. B. R. Carotenoid composition and vitamin A value of Brazilian loquat (Eriobotrya japonica Lindl.). Archivos Latinoamericanos de Nutricion, v. 45, n. 4, p. 336-339, 1995.

GROSS, J. et al. Carotenoids of Eriobotrya japonica. Phytochemistry, v. 12, n. 7, p. 1775-1782, 1973.

KON, M.; SHIMBA, R. Cultivar difference on carotenoids in loquat fruits. Nippon Shokuhin Kogyo Gakkaishi, v. 35, n. 6, p. 423-429, 1988.

OJIMA, M. et al. Cultura da nespereira. Campinas: Instituto Agronômico, 1999. (Boletim técnico, 185)

PAGANINI, C. et al. Análise da aptidão industrial de seis cultivares de maçãs, considerando suas avaliações físico-químicas: dados da safra 2001/2002. Ciência e Agrotecnologia, v. 28, n. 6, p. 1336-1343, 2004.

PROSKY, L. et al. Determination of insoluble, soluble and total dietary fibre in food and foods products. Interlabolatory study. Journal of the Association of Analitical Chemistry, v. 71, n. 5, p. 1017-1023, 1988.

SEYMOUR, J. T.; TAYLOR, J.; TUCKER, G. Biochemistry of fruit ripening. London: Chapman and Hall, 1993.

SOUCI, S. W.; FACHMANN, W.; KRAUT, H. Food Composition and Nutrition Tables. 5 ed. Stuttgart: Medpharm Scientific Publishers, 1994. 